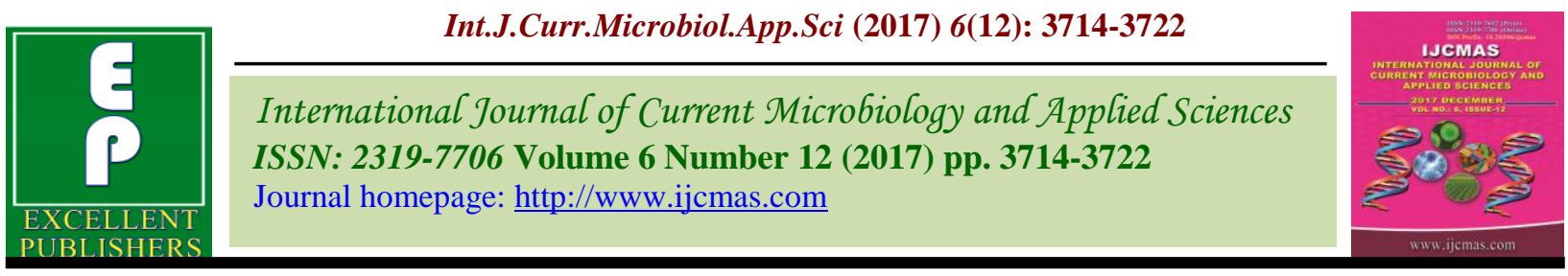

Original Research Article

https://doi.org/10.20546/ijcmas.2017.612.428

\title{
Selection and Performance of Peach [Prunus persica (L.) Batsch] Cultivars for Hybridization in Himachal Pradesh, India
}

\author{
Munmun Joshi*, Krishan Kumar, Nirmla Chauhan and Meena Kumari \\ Department of Fruit Science, Dr Y S Parmar University of Horticulture and Forestry, \\ Nauni, Solan, Himachal Pradesh-173230, India \\ *Corresponding author
}

A B S T R A C T

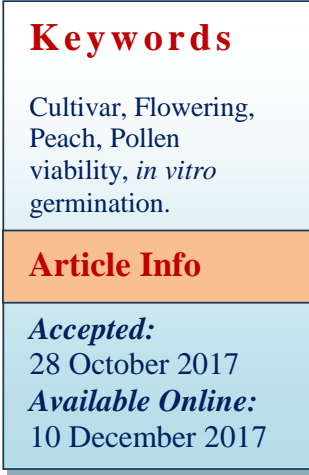

The present investigations were carried out in Peach Experimental Blocks of the Department of Fruit Science, Dr. Y S Parmar University of Horticulture and Forestry, Nauni-Solan (H P) during 2013-2014. Five cultivars of [Prunus persica (L.) Batsch] were evaluated for time and duration of flowering, viability of fresh and stored pollen grains with Acetocarmine and Erythrosin B, in vitro germination of stored and fresh pollen grains. Flower initiation was earliest in Tropic Beauty followed by Pratap, July Elberta and Redhaven were last to flowering in both the years. The duration of flowering extended from 16 days in Pratap to 24 days in Redhaven. In the next season, the flowering period extended from 14 days in Tropic Beauty and Saharanpur Prabhat to 16 days in Redhaven. Pollen viability of fresh pollen ranged from 92.71 to 95.84 per cent and 91.35 to 94.25 per cent in fresh pollen stained with Acetocarmine $(2 \%)$ and Erythrosin B $(0.04 \%)$. Germination was maximum (92.72\%) in 10 per cent sucrose solution.

\section{Introduction}

The peach [Prunus persica (L.) Batsch] is an important stone fruit grown worldwide. It belongs to family Rosaceae and is cultivated for table as well as for processing purpose. The peach fruit is valued as a good source of sugars (sucrose), proteins, minerals and vitamins. Peaches originated from China with a cultivation history of 4000 years. Its dispersal took place with trade and human migration to other parts of Asia, Europe and United States (Hesse, 1975). It goes through a dormant winter phase and requires a certain amount of winter chill to trigger its growth and production. Most peach cultivars require 500 to 1000 or more hours of cold below $7.2^{\circ}$ $\mathrm{C}$ to foliate and bloom normally in the spring.
It can be easily grown between latitudes extending from $10^{\circ}$ to $45^{\circ} \mathrm{N}$ and $18^{\circ}$ to $45^{\circ} \mathrm{S}$ in the whole world (Layne, 1987).

In India, introduction of cultivated peaches probably took place in the later half of the $19^{\text {th }}$ century. Today, it is being grown in the mid hill zone of Himalayas, extending from Jammu \& Kashmir, Himachal Pradesh, Uttrakhand. Besides this, the low chilling peaches are grown in the North Indian plains (Uttar Pradesh, Punjab, Haryana) and are expanding at a faster pace as they come early in the market during the season (mid-April onwards) and growers can get higher returns due to scarcity of other fresh fruits at that 
time. Major low-chill cultivars are Sharbati, Flordasun and Shan-i-Punjab followed by Pratap, Saharanpur Prabhat, etc.

In Himachal Pradesh, due to its wider adaptability and remunerative prices, though the peaches can be grown in the entire hill zone, however, Rajgarh valley of district Sirmour is the main centre of peach production. The total area under peach cultivation in Himachal Pradesh is 5076 hectares with the production of 8045 metric tons (Anonymous, 2016). The main cultivars of peach being grown in mid-hills of Himachal Pradesh are July Elberta, Redhaven, Sunhaven, etc. which require 700-950 chilling hours to come out of dormancy and matures late in the first half of July. Thus, there is an absolute and immediate need to develop peach cultivars which require low to moderate chilling and are early in maturation, so as to combat global warming and fetch good price in the market, respectively. To meet the needs of parent for hybridization present studies were conducted.

\section{Materials and Methods}

The present investigations were carried out in Peach Experimental Blocks of the Department of Fruit Science, Dr. Y S Parmar University of Horticulture and Forestry, Nauni-Solan $(\mathrm{H}$ $\mathrm{P})$. The experimental material used in the present study comprised six bearing trees of each of the peach cultivars (Table 1) grafted on wild peach seedling rootstock.

\section{Time and duration of flowering}

The field observations starting from initiation of flowering to the end of flowering in all the peach cultivars under study were recorded in 2013 and 2014 as follows: The date on which the first flower of different peach cultivars opened was recorded as time of initiation of flowering. The full bloom time in each cultivar was noted when more than 75 per cent of the flowers have opened and was recorded as date of peak flowering (full bloom). The date on which the fall of petals started in each cultivar under study was recorded as the end of flowering. The days from the date of first flower opening to the date of petal fall was taken as duration of flowering.

\section{Pollen studies}

Flower buds at balloon stage were collected from each peach cultivar used as pollen parent in hybridization work. The anthers were detached from the filaments and kept in the Petri dishes lined with non-sticky paper under partial shade. After anther dehiscence, the pollen grains were collected as indicated by shriveling of anthers and release of powdery mass. The pollen viability of fresh collected pollen grains was determined as explained in detail.

\section{Pollen storage}

Thoroughly air dried pollen grains were kept in the sterilized glass vials. Glass vials containing pollen were kept in the desiccators containing non-hydrated calcium-carbonate $\left(\mathrm{CaCO}_{3}\right)$ and were stored in the refrigerator at $4^{\circ} \mathrm{C}$ for its further use in hybridization work, which came into flowering at later stages. Prior to their use, the ability of stored pollen grains to germinate was determined following the standard procedures as per Kumar and Sharma (1997).

\section{In vitro pollen germination}

The freshly dehisced and stored pollen grains were subjected to in vitro germination tests for determining pollen viability. The different concentrations of sucrose i.e. 10, 15 and 20 per cent were prepared by dissolving 10, 15 and 20 grams of sucrose in $100 \mathrm{ml}$ of distilled 
water, respectively. Pollen germination and pollen tube growth was assessed for each cultivar under microscope after 24, 48 and 72 hours. The pollen grains having pollen tube at least two times longer than pollen size were considered to have germinated. Average percentage of germinated pollen grains under three microscopic fields was worked out.

\section{Results and Discussion}

\section{Time and duration of flowering}

Data pertaining to time and duration of flowering in peach cultivars are presented in Table 2.

\section{Time of initiation of flowering}

The flower initiation in 2013 was earliest in Tropic Beauty on $10^{\text {th }}$ January followed by Pratap on $13^{\text {th }}$ January, Saharanpur Prabhat on $25^{\text {th }}$ January. The last to initiate flowering were July Elberta and Redhaven on $2^{\text {nd }}$ and $3^{\text {rd }}$ March, respectively. In the next season the flower initiation was earliest in Tropic Beauty and Pratap on $28^{\text {th }}$ December followed by Saharanpur Prabhat on $21^{\text {st }}$ January. July Elberta and Redhaven were the last to initiate flowering on $12^{\text {th }}$ March and $15^{\text {th }}$ March, respectively.

\section{Time of full bloom}

The time of full bloom was recorded when more than 75 per cent flowers had opened. Full bloom in 2013 was observed earliest in TropicBeauty on $18^{\text {th }}$ January followed by Pratap on $19^{\text {th }}$ January, Saharanpur Prabhat on $1^{\text {st }}$ February, July Elberta on $11^{\text {th }}$ March and Redhaven on $14^{\text {th }}$ March. Similarly in 2014, the time of full bloom was earliest in Tropic Beauty on $2^{\text {nd }}$ January followed by Pratap on $5^{\text {th }}$ January, Saharanpur Prabhat on $29^{\text {th }}$ January, Redhaven on $20^{\text {th }}$ March and July Elberta on $24^{\text {th }}$ March.

\section{Time of end of flowering (petal fall)}

In the year 2013, the earliest petal fall was observed in TropicBeauty on $27^{\text {th }}$ January followed by Pratap on $28^{\text {th }}$ January, Saharanpur Prabhat on $12^{\text {th }}$ February, July Elberta on $23^{\text {rd }}$ March and Redhaven on $26^{\text {th }}$ March.

In 2014 also, the petal fall was earliest in Tropic Beauty on $10^{\text {th }}$ January followed by Pratap on $11^{\text {th }}$ January, Saharanpur Prabhat on $4^{\text {th }}$ February, July Elberta on $26^{\text {th }}$ March and Redhaven on $30^{\text {th }}$ March.

\section{Duration of flowering}

The duration of flowering during 2013 extended from 16 days in Pratap to 24 days in Redhaven. In the year 2014, the flowering period extended from 14 days in Tropic Beauty and Saharanpur Prabhat to 16 days in Redhaven.

It is well known that bloom time in peach is primarily the indicator of chilling requirement, and is consistent over years and environment (Scorza and Sherman, 1996). Similar observations have been recorded in the present study.

Present findings are in line with Ayaz et al., (2001) who studied different flowering characteristics viz., first flower opening, full bloom and blooming end and observed marked difference in flowering characteristics among different cultivars of peach. This may be due to varying temperature regimes during the period of studies.

\section{Pollen viability studies}

The viability of fresh and stored pollen grains of peach cultivars used as male parents in hybridization was determined by following tests: 


\section{viability of fresh pollen grains}

\section{Acetocarmine (2\%) test}

Pollen viability recorded in different peach cultivars is presented in Table 4 and Plate 2. The data reveals that pollen viability of various peach cultivars differed significantly, when pollen grains were stained with 2.0 per cent acetocarmine. Maximum pollen viability in 2013 (97.34\%) and 2014 (94.33\%) was observed in Saharanpur Prabhat. Minimum pollen viability was recorded to be 93.99 per cent in Pratap in 2013 whereas it was minimum (90.99\%) in 2014 in Tropic Beauty (Table 3).

\section{Erythrosin B (0.04\%) test}

Pollen viability with the erythrosin B (0.04\%) recorded in different peach cultivars is presented in Table 4 and Plate 3. The data reveals that pollen viability of various peach cultivars differed significantly, when fresh pollen grains were stained with erythrosin B solution $(0.04 \%)$. Maximum pollen viability to the extent of 96.30 per cent and 94.53 per cent was observed in Pratap in 2013 and 2014, respectively. In Saharanpur Prabhat, pollen viability was 94.54 per cent and 93.96 per cent in 2013 and 2014, respectively. Minimum pollen viability was observed in Tropic Beauty during $2013(92.46 \%)$ and 2014 (90.24\%).

\section{Pollen viability of stored pollen grains}

\section{Acetocarmine (2\%) test}

Viability recorded in stored pollen grains of different peach cultivars is presented in Table $6 \mathrm{a}$. The data reveals that pollen viability of various peach cultivars differed significantly, when stored pollen grains were stained with acetocarmine solution (2\%). Maximum pollen viability (93.40\%) in 2013 was observed in Saharanpur Prabhat and minimum (90.93\%) was in Tropic Beauty. In 2014, maximum pollen viability $(92.67 \%)$ was recorded in Pratap and minimum (88.10\%) in Tropic Beauty, respectively. Pollen viability in Pratap was recorded as 90.91 per cent in 2013. In 2014, pollen viability in Saharanpur Prabhat was recorded as 91.81 per cent.

\section{Erythrosin B (0.04\%) test}

Pollen viability with the erythrosin B in stored pollen grains of different peach cultivars is presented in Table $6 \mathrm{~b}$. The data reveals that pollen viability of various cultivars differed significantly when pollen grains were stained with erythrosin B solution $(0.04 \%)$. Maximum pollen viability in 2013 (94.86\%) and in $2014(91.90 \%)$ was observed in cv. Saharanpur Prabhat. In Tropic Beauty pollen, viability was 92.31 per cent and 88.99 per cent in 2013 and 2014, respectively. Minimum pollen viability in $2013(91.52 \%)$ and in $2014(88.59 \%)$ was observed in Pratap (TA-170).

Shivanna et al., (1991) reported that pollen viability is generally considered to indicate the ability of the pollen grain to perform its function of delivering sperm cell to the embryo sac following compatible pollination. The percentage of viability through Acetocarmine is higher because protein containing but metabolically dead pollen grains are also counted as viable whereas erythrosine $\mathrm{B}$ test is a dye excluding test. The observations on pollen viability are in agreement with the findings of Kahlon and Chhatwal (1978); Meena et al., (2011).

\section{In vitro pollen germination test}

The observations in vitro pollen germination of fresh pollen grains of peach cultivars in varying concentration of sucrose at room temperature recorded after 24 and 48 hours are presented in Table 5a, b, c and Plate 4. 
Table.1 List of peach cultivars

\begin{tabular}{|c|c|c|c|c|}
\hline Peach cultivar & Parentage & Chill Units (CU) & Time of flowering & Time of maturity \\
\hline July Elberta & Unknown & $850-900$ & $\begin{array}{c}\text { Late (First week of } \\
\text { March) }\end{array}$ & $\begin{array}{c}\text { Late (First week } \\
\text { of July) }\end{array}$ \\
\hline Redhaven & Halehaven $\times$ Kalhaven & 950 & $\begin{array}{c}\text { Late (First week of } \\
\text { March) }\end{array}$ & $\begin{array}{c}\text { Late (First week } \\
\text { of July) }\end{array}$ \\
\hline TropicBeauty & Florida Prince $\times$ FL3-2 & 150 & $\begin{array}{c}\text { Early (Last week of } \\
\text { December to second } \\
\text { week of January) }\end{array}$ & $\begin{array}{l}\text { Early (Last week } \\
\text { of April) }\end{array}$ \\
\hline Pratap (TA-170) & $\begin{array}{c}\text { A selection from } \\
\text { Florida breeding } \\
\text { programme }\end{array}$ & $250-300$ & $\begin{array}{l}\text { Early (Last week of } \\
\text { December to second } \\
\text { week of January) }\end{array}$ & $\begin{array}{l}\text { Early (Last week } \\
\text { of April) }\end{array}$ \\
\hline $\begin{array}{c}\text { Saharanpur } \\
\text { Prabhat }\end{array}$ & Sharbati $\times$ Flordasun & $<500$ & $\begin{array}{c}\text { Early (Last week of } \\
\text { January) }\end{array}$ & $\begin{array}{c}\text { Early (First week } \\
\text { of May) }\end{array}$ \\
\hline
\end{tabular}

Table.2 Time and duration of flowering in peach cultivars

\begin{tabular}{|c|c|c|c|c|c|c|c|c|}
\hline \multirow{2}{*}{ Cultivars } & \multicolumn{2}{|c|}{$\begin{array}{c}\text { Time of initiation } \\
\text { of flowering }\end{array}$} & \multicolumn{2}{c|}{$\begin{array}{c}\text { Time of full } \\
\text { bloom } \\
\text { (> 75 \%) }\end{array}$} & $\begin{array}{c}\text { Time of end of } \\
\text { flowering (petal } \\
\text { fall) }\end{array}$ & \multicolumn{2}{c|}{$\begin{array}{c}\text { Duration of } \\
\text { flowering } \\
\text { (Days) }\end{array}$} \\
\cline { 2 - 9 } & $\mathbf{2 0 1 3}$ & $\mathbf{2 0 1 4}$ & $\mathbf{2 0 1 3}$ & $\mathbf{2 0 1 4}$ & $\mathbf{2 0 1 3}$ & $\mathbf{2 0 1 4}$ & $\mathbf{2 0 1 3}$ & $\mathbf{2 0 1 4}$ \\
\hline TropicBeauty & $10 / 01$ & $28 / 12$ & $18 / 01$ & $02 / 01$ & $27 / 01$ & $10 / 01$ & 18 & 14 \\
\hline $\begin{array}{c}\text { Pratap } \\
\text { (TA-170) }\end{array}$ & $13 / 01$ & $28 / 12$ & $19 / 01$ & $05 / 01$ & $28 / 01$ & $11 / 01$ & 16 & 15 \\
\hline $\begin{array}{c}\text { Saharanpur } \\
\text { Prabhat }\end{array}$ & $25 / 01$ & $21 / 01$ & $01 / 02$ & $29 / 01$ & $12 / 02$ & $04 / 02$ & 19 & 14 \\
\hline July Elberta & $02 / 03$ & $12 / 03$ & $14 / 03$ & $20 / 03$ & $23 / 03$ & $26 / 03$ & 22 & 15 \\
\hline Redhaven & $03 / 03$ & $15 / 03$ & $11 / 03$ & $24 / 03$ & $26 / 03$ & $30 / 03$ & 24 & 16 \\
\hline
\end{tabular}

Table.3 Viability of fresh pollen with acetocarmine (2\%)

\begin{tabular}{|c|c|c|c|}
\hline \multirow{2}{*}{ Cultivar } & \multicolumn{3}{|c|}{ Pollen viability (\%) } \\
\cline { 2 - 4 } & $\mathbf{2 0 1 3}^{*}$ & $\mathbf{2 0 1 4}^{*}$ & Pooled $^{*}$ \\
\hline TropicBeauty & $94.42(9.77)$ & $90.99(9.59)$ & $92.71(9.68)$ \\
\hline Pratap (TA-170) & $93.99(9.75)$ & $91.01(9.59)$ & $92.50(9.67)$ \\
\hline Saharanpur Prabhat & $97.34(9.92)$ & $94.33(9.76)$ & $95.84(9.84)$ \\
\hline CD $_{\mathbf{0 . 0 5}}$ & 0.12 & 0.13 & 0.08 \\
\hline
\end{tabular}

*Figures in parenthesis are square root transformed values

Table.4 Viability of fresh pollen with erythrosin B $(0.04 \%)$

\begin{tabular}{|c|c|c|c|}
\hline \multirow{2}{*}{ Cultivar } & \multicolumn{3}{|c|}{ Pollen viability (\%) } \\
\cline { 2 - 4 } & $\mathbf{2 0 1 3}^{*}$ & $\mathbf{2 0 1 4}^{*}$ & Pooled* \\
\hline TropicBeauty & $92.46(9.67)$ & $90.24(9.55)$ & $91.35(9.61)$ \\
\hline Pratap (TA-170) & $96.30(9.86)$ & $94.53(9.77)$ & $95.42(9.82)$ \\
\hline Saharanpur Prabhat & $94.54(9.77)$ & $93.96(9.75)$ & $94.25(9.76)$ \\
\hline CD $_{\mathbf{0 . 0 5}}$ & 0.13 & 0.16 & 0.10 \\
\hline
\end{tabular}

*Figures in parenthesis are square root transformed values 
Table.5a In vitro germination of fresh pollen in sucrose (10\%)

\begin{tabular}{|c|c|c|c|c|c|c|}
\hline \multirow{2}{*}{ Cultivars } & \multicolumn{3}{|c|}{ After 24 hours } & \multicolumn{3}{c|}{ After 48 hours } \\
\cline { 2 - 7 } & $\mathbf{2 0 1 3}^{* *}$ & $\mathbf{2 0 1 4} * *$ & Pooled & $\mathbf{2 0 1 3}^{*}$ & $\mathbf{2 0 1 4}^{*}$ & Pooled \\
\hline Tropic Beauty & 37.73 & 45.31 & 41.52 & 87.97 & 91.99 & 89.98 \\
& $(37.86)$ & $(42.29)$ & $(41.59)$ & $(9.43)$ & $(9.64)$ & $(9.54)$ \\
\hline Pratap (TA- & 36.70 & 41.36 & 39.03 & 85.84 & 91.53 & 88.68 \\
170) & $(37.26)$ & $(40.06)$ & $(38.66)$ & $(9.32)$ & $(9.62)$ & $(9.47)$ \\
\hline Saharanpur & 41.70 & 45.44 & 43.57 & 90.84 & 94.60 & 92.72 \\
Prabhat & $(40.20)$ & $(42.36)$ & $(41.28)$ & $(9.58)$ & $(9.78)$ & $(9.68)$ \\
\hline CD $_{\mathbf{0 . 0 5}}$ & 2.14 & 2.02 & 1.84 & 0.19 & 0.07 & 0.09 \\
\hline
\end{tabular}

*Figures in parenthesis are square root transformed values

**Figures in parenthesis are angular transformed values

Table.5b In vitro germination of fresh pollen in sucrose (15\%)

\begin{tabular}{|c|c|c|c|c|c|c|}
\hline \multirow{2}{*}{ Cultivars } & \multicolumn{3}{|c|}{ After 24 hours } & \multicolumn{3}{c|}{ After 48 hours } \\
\cline { 2 - 7 } & $\mathbf{2 0 1 3}^{*}$ & $\mathbf{0 1 4} *$ & Pooled & $\mathbf{2 0 1 3}^{* *}$ & $\mathbf{2 0 1 4}_{* *}^{*}$ & Pooled \\
\hline TropicBeauty & 17.07 & 28.47 & 22.77 & 40.74 & 59.76 & 50.25 \\
& $(4.25)$ & $(5.42)$ & $(4.84)$ & $(39.65)$ & $(50.61)$ & $(45.13)$ \\
\hline Pratap & 16.93 & 27.60 & 22.27 & 34.27 & 56.74 & 45.51 \\
(TA-170) & $(4.23)$ & $(5.35)$ & $(4.80)$ & $(35.76)$ & $(48.86)$ & $(42.31)$ \\
\hline Saharanpur & 15.09 & 29.60 & 22.35 & 42.24 & 62.23 & 52.24 \\
Prabhat & $(4.01)$ & $(5.53)$ & $(4.77)$ & $(40.51)$ & $(52.06)$ & $(46.29)$ \\
\hline CD $_{\mathbf{0 . 0 5}}$ & 0.16 & 0.12 & N.S. & 2.67 & 1.45 & 1.46 \\
\hline
\end{tabular}

*Figures in parenthesis are square root transformed values

**Figures in parenthesis are angular transformed value

Table.5c In vitro germination of fresh pollen in sucrose (20\%)

\begin{tabular}{|c|c|c|c|c|c|c|}
\hline \multirow{2}{*}{ Cultivars } & \multicolumn{3}{|c|}{ After 24 hours } & \multicolumn{3}{c|}{ After 48 hours } \\
\cline { 2 - 7 } & $\mathbf{2 0 1 3}^{*}$ & $\mathbf{2 0 1 4}$ & Pooled & $\mathbf{2 0 1 3}^{*}$ & $\mathbf{2 0 1 4}$ & Pooled \\
\hline Tropic Beauty & 8.71 & 15.83 & 12.27 & 10.93 & 19.60 & 15.27 \\
& $(3.12)$ & $(4.10)$ & $(3.61)$ & $(3.45)$ & $(4.54)$ & $(4.00)$ \\
\hline Pratap (TA-170) & 7.81 & 15.07 & 11.44 & 10.84 & 16.59 & 13.72 \\
& $(2.96)$ & $(4.01)$ & $(3.49)$ & $(3.44)$ & $(4.19)$ & $(3.82)$ \\
\hline Saharanpur Prabhat & 9.51 & 16.56 & 13.04 & 12.01 & 21.99 & 17.00 \\
& $(3.24)$ & $(4.19)$ & $(3.72)$ & $(3.61)$ & $(4.79)$ & $(4.20)$ \\
\hline CD $_{\mathbf{0 . 0 5}}$ & 0.18 & 0.12 & 0.10 & 0.12 & 0.21 & 0.19 \\
\hline
\end{tabular}

*Figures in parenthesis are square root transformed values

Table.6a Viability of stored pollen with acetocarmine (2\%)

\begin{tabular}{|c|c|c|c|}
\hline \multirow{2}{*}{ Cultivar } & \multicolumn{3}{|c|}{ Pollen viability (\%) } \\
\cline { 2 - 4 } & $\mathbf{( 2 0 1 3}^{*}$ & $\mathbf{( 2 0 1 4}^{*}$ & Pooled $^{*}$ \\
\hline TropicBeauty & $90.03(9.54)$ & $88.1(9.45)$ & $89.07(9.55)$ \\
\hline Pratap (TA-170) & $90.91(9.59)$ & $92.67(9.68)$ & $91.79(9.64)$ \\
\hline Saharanpur Prabhat & $93.40(9.72)$ & $91.81(9.63)$ & $92.61(9.68)$ \\
\hline CD $_{\mathbf{0 . 0 5}}$ & 0.14 & 0.17 & 0.10 \\
\hline
\end{tabular}

*Figures in parenthesis are square root transformed values 
Table.6b Viability of stored pollen with erythrosin B $(0.04 \%)$

\begin{tabular}{|c|c|c|c|}
\hline \multirow{2}{*}{ Cultivar } & \multicolumn{3}{|c|}{ Pollen viability (\%) } \\
\cline { 2 - 4 } & $\mathbf{2 0 1 3}^{*}$ & $\mathbf{2 0 1 4}^{*}$ & Pooled* $^{*}$ \\
\hline TropicBeauty & $92.31(9.66)$ & $88.99(9.49)$ & $90.65(9.58)$ \\
\hline Pratap (TA-170) & $91.52(9.62)$ & $88.59(9.46)$ & $90.15(9.54)$ \\
\hline Saharanpur Prabhat & $94.86(9.79)$ & $91.90(9.63)$ & $93.38(9.71)$ \\
\hline CD $_{\mathbf{0 . 0 5}}$ & 0.13 & 0.14 & 0.09 \\
\hline
\end{tabular}

*Figures in parenthesis are square root transformed values

Table.7a In vitro germination of stored pollen in sucrose (10\%)

\begin{tabular}{|c|c|c|c|c|c|c|}
\hline \multirow{2}{*}{ Cultivars } & \multicolumn{3}{|c|}{ After 24 hours } & \multicolumn{3}{c|}{ After 48 hours } \\
\cline { 2 - 7 } & $\mathbf{( 2 0 1 3 )}^{* *}$ & $(\mathbf{2 0 1 4}) * *$ & Pooled & $\mathbf{( 2 0 1 3 )}^{*}$ & $(\mathbf{2 0 1 4}) *$ & Pooled \\
\hline Tropic Beauty & 34.19 & 42.71 & 38.45 & 83.53 & 89.63 & 86.58 \\
& $(35.74)$ & $(40.79)$ & $(38.27)$ & $(9.19)$ & $(9.52)$ & $(9.36)$ \\
\hline Pratap (TA-170) & 32.79 & 38.04 & 35.42 & 82.97 & 87.83 & 85.4 \\
& $(34.89)$ & $(38.06)$ & $(36.48)$ & $(9.16)$ & $(9.43)$ & $(9.35)$ \\
\hline Saharanpur & 38.26 & 41.27 & 39.77 & 86.79 & 90.91 & 88.85 \\
Prabhat & $(38.19)$ & $(39.95)$ & $(39.07)$ & $(9.37)$ & $(9.59)$ & $(9.48)$ \\
\hline CD $_{\mathbf{0 . 0 5}}$ & 2.09 & 1.8 & 1.3 & 0.17 & 0.06 & 0.08 \\
\hline
\end{tabular}

*Figures in parenthesis are square root transformed values

**Figures in parenthesis are angular transformed values

Table.7b In vitro germination of stored pollen in sucrose (15\%)

\begin{tabular}{|c|c|c|c|c|c|c|}
\hline \multirow{2}{*}{ Cultivars } & \multicolumn{3}{|c|}{ After 24 hours } & \multicolumn{3}{c|}{ After 48 hours } \\
\cline { 2 - 7 } & $\mathbf{2 0 1 3}^{*}$ & $\mathbf{2 0 1 4} *$ & Pooled & $\mathbf{2 0 1 3}^{* *}$ & $\mathbf{2 0 1 4} * *$ & Pooled \\
\hline TropicBeauty & 15.29 & 26.43 & 20.86 & 37.96 & 56.99 & 47.48 \\
& $(4.03)$ & $(5.24)$ & $(4.64)$ & $(38.01)$ & $(49)$ & $(43.6)$ \\
\hline Pratap & $15.81(4.1)$ & 25.99 & 20.9 & 32.29 & 54.29 & 43.29 \\
(TA-170) & & $(5.19)$ & $(4.65)$ & $(34.56)$ & $(47.44)$ & $(41)$ \\
\hline Saharanpur & 14.01 & 27.72 & 20.87 & 38.11 & 58.3 & 48.21 \\
Prabhat & $(3.87)$ & $(5.36)$ & $(4.62)$ & $(38.1)$ & $(49.76)$ & $(43.93)$ \\
\hline CD $_{\mathbf{0 . 0 5}}$ & 0.13 & 0.12 & 0.08 & 2.48 & 1.43 & 1.30 \\
\hline
\end{tabular}

*Figures in parenthesis are square root transformed values

**Figures in parenthesis are angular transformed value

Table.7c In vitro germination of stored pollen grains in sucrose (20\%)

\begin{tabular}{|c|c|c|c|c|c|c|}
\hline \multirow{2}{*}{ Cultivars } & \multicolumn{3}{|c|}{ After 24 hours } & \multicolumn{3}{c|}{ After 48 hours } \\
\cline { 2 - 7 } & $\mathbf{2 0 1 3}$ & $\mathbf{2 0 1 4} *$ & Pooled & $\mathbf{2 0 1 3}^{*}$ & $\mathbf{2 0 1 4} *$ & Pooled \\
\hline Tropic Beauty & 5.24 & $13.49(3.8)$ & 9.37 & 8.67 & 18.02 & 13.35 \\
& $(2.49)$ & & $(8.0)$ & $(3.11)$ & $(4.36)$ & $(3.74)$ \\
\hline Pratap (TA-170) & 4.16 & $11.97(3.6)$ & 8.15 & 8.63 & 14.3 & 11.47 \\
& $(2.27)$ & & $(3.0)$ & $(3.1)$ & $(3.91)$ & $(3.51)$ \\
\hline Saharanpur & 5.64 & 13.71 & 9.68 & 10.00 & 18.7 & 14.35 \\
Prabhat & $(2.56)$ & $(3.83)$ & $(3.2)$ & $(3.32)$ & $(4.42)$ & $(3.9)$ \\
\hline CD $_{\mathbf{0 . 0 5}}$ & 0.24 & 0.17 & 0.14 & 0.15 & 0.37 & 0.17 \\
\hline
\end{tabular}

*Figures in parenthesis are square root transformed values 
The data presented in Table 5a indicates that in vitro pollen germination after 24 hours in 10 per cent sucrose was recorded significantly higher in Saharanpur Prabhat i.e., 41.70 per cent (2013), 45.44 per cent (2014) and 43.57 per cent (pooled). But in 2014, Tropic Beauty was found to be at par with Saharanpur Prabhat.

In vitro pollen germination after 48 hours was also recorded significantly higher in Saharanpur Prabhat in 2013 (90.84\%), in 2014 (94.60\%) as well as in pooled data (92.72\%), but in 2013 it was at par with Tropic Beauty.

The data presented in Table $5 \mathrm{~b}$ revealed that in vitro pollen germination after 24 hours in 15 per cent sucrose was recorded significantly higher in Tropic Beauty (17.07\%) which was found at par with Pratap (16.93\%) in 2013. Similar observations were recorded during 2014 where Tropic Beauty (28.47\%) was found at par with Pratap (27.60\%).

However, pooled data showed no statistical difference. In vitro pollen germination after 48 hours was observed significantly higher in Saharanpur Prabhat i.e., 42.24 per cent (2013), 62.23 per cent (2014) and 52.24 per cent (pooled). But pooled data in 2014 indicated Saharanpur Prabhat to be at par with Tropic beauty in respect of in vitro germination of fresh pollen grains.

The data presented in Table $5 \mathrm{c}$ revealed that in vitro pollen germination after 24 hours in 20 per cent sucrose was significantly higher in Saharanpur Prabhat in $2013(9.51 \%)$ and in $2014(16.56 \%)$ as well as pooled values than in Pratap but was at par with Tropic Beauty. After 48 hours also, Saharanpur Prabhat recorded significantly higher values i.e., 12.01 per cent (2013), 21.99 per cent (2014) and 17.00 per cent (pooled) in respect to in vitro germination of fresh pollen grains.

\section{In vitro germination of stored pollen grains}

The observations in vitro germination in one month stored pollen grains of various cultivars in different concentration of sucrose solution at room temperature recorded after 24 and 48 hours are presented in Table 7a, b, c.

The data presented in Table $7 \mathrm{a}$ revealed that in 10 per cent sucrose in vitro pollen germination after 24 hours was significantly higher in Saharanpur Prabhat (38.26\%) in 2013 than in Pratap (32.79\%) and Tropic Beauty (34.19\%) which was at par with each other.

In 2014, Tropic Beauty was higher (42.71\%) was found at par with Saharanpur Prabhat (41.27\%) but significantly higher than Pratap $(38.04 \%)$. For pooled values, Saharanpur Prabhat was significantly higher $(39.77 \%)$ than Pratap $(35.42 \%)$ but at par with Tropic Beauty $(38.45 \%)$.

After 48 hours, Saharanpur Prabhat was observed significantly higher i.e., 86.79 per cent (2013), 90.91 per cent (2014) and 88.85 per cent (pooled) in respect of in vitro pollen germination in stored pollen grains.

The data presented in Table $7 \mathrm{~b}$ revealed that in 15 per cent sucrose in vitro pollen germination after 24 hours in peach cultivars was significantly higher in 2013 in Pratap (15.81\%) which was found to be at par with Tropic Beauty (15.29\%). In 2014, Saharanpur Prabhat recorded maximum $(27.72 \%)$ pollen germination which was found at par with Tropic Beauty $(26.43 \%)$. For pooled data none of the cultivars showed significant differences. After 48 hours, Saharanpur Prabhat was observed significantly higher i.e., 38.11 per cent (2013), 58.3 per cent (2014) and 48.21 per cent (pooled) in respect of in vitro germination in stored pollen grains.

The data presented in Table $7 \mathrm{c}$ revealed that in vitro pollen germination after 24 hours in 20 per cent sucrose peach cultivars was significantly higher in Saharanpur Prabhat i.e., 5.64 per cent (2013), 13.71 per cent (2014) and 9.68 per cent (pooled).

Tropic Beauty was reported to be at par with Saharanpur Prabhat i.e., 5.24 per cent (2013) and 13.49 per cent (2014). 
After 48 hours, Saharanpur Prabhat was recorded significantly higher i.e., 10.00 per cent (2013), 18.70 per cent (2014) and 14.35 (pooled) which was found to be at par with Tropic Beauty in 2014 as well as in pooled values.

The in vitro pollen germination is considered more reliable and more convenient method to assess the level of viability compared to staining tests (Griggs et al., 1953).

Meena et al., (2011) reported maximum pollen germination under 10 per cent sucrose solution followed by 15 and 20 per cent and concluded that a higher concentration of sucrose (above optimum) was not conducive for pollen germination.

Present investigations with regard to pollen germination are in close agreement with the findings of Singh (1967), Kahlon and Chhatwal (1978).

\section{References}

Anonymous. 2013. Horticulture Development in Himachal Pradesh- At a Glance (hpagrisnet.gov.in).

Ayaz M, Akhtar I and Ahad S F. 2001. Comparison of exotic peach varieties at two different altitudes in the upper and lower Swat. Online Journal of Biological Sciences. 1(5): 324-325.

Griggs W H, Vansell $\mathrm{G} \mathrm{H}$ and Iwakiri B T. 1953. The storage of hand collected and bee collected pollen in home freezer. Proceedings of the American Society for Horticultural Science, 62: 304-305.
Hesse C O. 1975. Peaches. In: Advances in Fruit Breeding. Janick J and Moore J N (eds). Purdue University Press, West Lafayette. 285-336.

Kahlon P S and Chhatwal G S. 1978. Studies on floral biology of peach Prunus persica (Batsch). Haryana Journal of Horticultural Sciences, 7(3/4): 152-155.

Kumar K and Sharma S D. 1997. Elementary Fruit Breeding: A Practical Manual. Department of FB\&GR, UHF, NauniSolan (HP).

Layne R E C. 1987. Peach rootstocks. In: Rootstock for Fruit Crops. Rom R C and Carlson R F (eds). A. Wiley-Inter Science Publication, Canada 185-216.

Meena B L, Chandra A, Kaul M K, Meena R K and Meena H R. 2011. Study on floral biology in peach cultivars in Sriganganagar district of Rajasthan. Progressive Horticulture 42(2): 315-319.

Scorza R and Sherman W B. 1996. Peaches. In: Fruit Breeding: Tree and Tropical Fruits. Janick $\mathrm{J}$ and Moore $\mathrm{J} \mathrm{N}$ (eds). Wiley, New York 1: 325-440.

Sharma D P, Thakur S and Sharma N. 2012. Comparative studies on growth, flowering and fruiting behaviour of new introductions of peach cultivars with July Elberta under mid hill conditions of Himachal Pradesh. Progressive Horticulture 44(2): 206-210.

Shivanna K R, Linskens H F and Cresti M. 1991. Pollen viability and pollen vigor. Theoretical and Applied Genetics 81(1): 38-42.

Singh G N. 1967. Studies on floral biology of peaches under sub-tropical condition. The Punjab Horticultural Journal 7(3/4): 103107.

\section{How to cite this article:}

Munmun Joshi, Krishan Kumar, Nirmla Chauhan and Meena Kumari. 2017. Selection and Performance of Peach [Prunus persica (L.) Batsch] Cultivars for Hybridization in Himachal Pradesh, India. Int.J.Curr.Microbiol.App.Sci. 6(12): 3714-3722.

doi: https://doi.org/10.20546/ijcmas.2017.612.428 